\title{
Milk as a source of lactose, vitamins and minerals
}

\section{By J. W. G. Porter, National Institute for Research in Dairying, Shinfield, Reading}

Milk is an almost complete single food and the more important contributions milk and milk products make to our daily needs for energy, protein, calcium and certain vitamins are summarized in Table $\mathrm{I}$. Besides its general role as an important component of the mixed diets eaten by most of the population, cow's milk has a special value in infant nutrition through serving as the source of most of the ingredients used in the preparation of infant milk foods. In this paper present knowledge of the role in human nutrition of the lactose, vitamins and minerals of milk is summarized and some indication is given of topics that require further investigation.

\section{Lactose}

Typical bulk cow's milk contains $37 \mathrm{~g}$ fat, $33 \mathrm{~g}$ protein and $47 \mathrm{~g}$ lactose/1, so that lactose contributes nearly one-third of the total energy supplied by liquid milk. Human milk contains $42 \mathrm{~g}$ fat, I $\mathrm{g}$ protein and $74 \mathrm{~g}$ lactose/1 (Department of Health \& Social Security, 1977). At present about $55 \%$ of the milk produced in the UK is consumed as liquid milk; the remainder is manufactured and the principal products, butter and cheese, contain little or no lactose which passes, as the major component, into the corresponding by-products, skim milk and whey (dried skim milk contains $500 \mathrm{~g}$ and dried whey $700 \mathrm{~g}$ lactose $/ \mathrm{kg}$ ). As milk production in the UK is tending to increase and consumption of liquid milk to decrease, the amount of milk moving into manufacture, and hence the amount of these by-products, is likely further to increase. During 1977 production of butter and cheese in the UK gave rise to skim milk containing about 55000 tonnes and whey containing about 60000 tonnes of lactose.

Table 1. Percentage contribution of dairy products to nutrient intakes in UK (1976)*

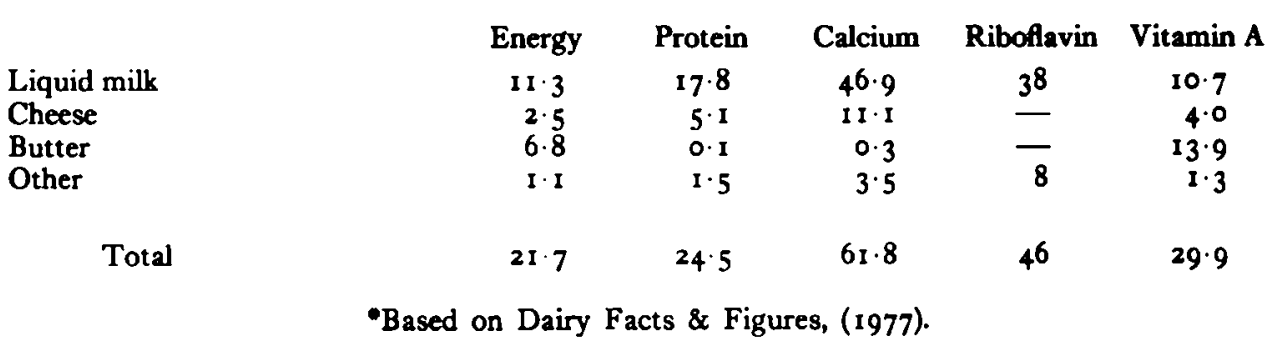


Lactose in nutrition. Lactose is a disaccharide and as such it has to be broken down by the enzyme lactase ( $\beta$-galactosidase) $(E C$ 3.2.1.23) to its constituent glucose and galactose before absorption in the small intestine and utilization by the body can occur. Newborn mammals are well endowed with lactase but production of the enzyme falls off rapidly after weaning, so that adult animals are able to digest only small amounts of lactose. When larger quantities are given the undigested lactose passes into the large intestine where it is broken down by bacterial action; the resulting organic acids may be of benefit to the animal, but the raised osmotic pressure caused by undigested lactose in the lower gut often causes bloating and diarrhoea. Similar considerations apply to man and adults of many coloured races are deficient in lactase, though most Caucasian populations and some coloured races with a history of milk drinking appear to have acquired a mutant gene that maintains lactase secretion into adult life (Cook, 1973; Dahlqvist, 1977).

It is probable that lactose is not an essential nutrient, even for infants, since any galactose required for the formation of cerebrosides and glycoproteins can be made in the liver from glucose. Even in young animals lactose is digested more slowly than other carbohydrates; this leads to the presence of undigested lactose in the distal part of the small intestine and favours the establishment there of a lactobacillus flora which maintains a low $\mathrm{pH}$ value in the intestinal contents. This low $\mathrm{pH}$ may be in part responsible for the effect that lactose has in enhancing the absorption of certain minerals, particularly calcium, by animals, though possibly not by infants (Fomon, 1974).

Effects of processing. Lactose in milk is little affected by traditional heat processing procedures or during drying, though particularly severe heating or prolonged storage of products may lead to Maillard reaction with milk proteins, and in-bottle sterilization of infant milk foods may result in the isomerization of a small proportion of the lactose to lactulose ( $4-\beta-d$-galactosido ( $1: 4) d$-glucose), the corresponding keto sugar, which is not digested in the intestine and which may cause diarrhoea (Hendrickse, Wooldridge \& Russell, 1977). Increasing awareness of possible problems arising from lactase deficiency, and hence some degree of lactose intolerance, has led to the development of procedures for the enzymic hydrolysis of lactose in UHT milk to glucose and galactose (Dahlqvist, Asp, Burvall \& Rausing, r 977). Such milk retained its nutritional quality during storage for several weeks, but evaporation and spray drying caused loss of protein quality due to extensive Maillard reaction between the monosaccharides and the milk proteins (Burvall, Asp, Dahlqvist \& Öste, 1977).

Utilization of lactose from milk by-products. Whey contains about one-third of the solids of the milk from which it was derived and about $70 \%$ of these solids is lactose. In the past much of the whey produced has been used for feeding pigs and calves, but recently, as the amounts of whey available have increased, other outlets have been sought and whey has been shown to be a useful feed for cattle, given either as liquid whey (Rogers, Welch, Nilson \& Smith, 1977) or after causing the lactose in it to react with urea to give a feed containing lactosyl ureide, a source of 
non-protein nitrogen with a built-in supply of readily available carbohydrate (McAllan, Merry \& Smith, 1975). At the same time much effort has been devoted to finding uses for whey and its components in human nutrition.

Whey has been used for many years for the preparation of lactose and for the preparation of dried whey powder for use in foods and feeds. Such procedures denature the whey proteins and impair their nutritional and functional properties. Since much of the commercial value of whey lies in these proteins, particular attention has been given to the development of techniques of reverse osmosis, ultrafiltration, gel filtration and electrodialysis that have afforded methods of fractionating whey and allowing recovery of the whey proteins in an undenatured form. Lactose can be crystallized from the permeate, filtrate or dialysate from the procedures but, as the scope for using lactose itself in foods appears to be limited, current interest lies in the use of enzymic hydrolysis to yield glucose-galactose mixtures which have various uses, including those as substrates for microbial fermentation or, after concentration, the preparation of syrups that are sweeter than lactose and may compete with sucrose and starch hydrolysates as sweeteners in the food industry.

Skim milk contains about one-half of the solids of whole milk and about one-half of these solids is lactose. So far less attention has been given to the utilization of lactose from skim milk than from whey but, as the mountains of skim milk powder grow, there is an urgent need further to develop fractionation procedures and to find new ways of using the components of skim milk in human nutrition. Enzymic hydrolysis of lactose in skim milk used for the manufacture of yoghurt may have merit since it enables a sweetened product to be made without the need for adding sucrose (Thomasow \& Klostermeyer, 1977).

\section{Vitamins}

Values for the concentrations of the vitamins in typical bulk cows' milk and in mature human milk are shown in Table 2. The concentrations in cows' milk of the water-soluble vitamins and of vitamin $\mathrm{K}$ are little affected by breed, feed, season or

Table 2. Concentrations of vitamins in coros' and human milk

\begin{tabular}{|c|c|c|c|c|c|}
\hline \multicolumn{3}{|c|}{$(\mathrm{mg} / \mathrm{l})$} & & \multicolumn{2}{|c|}{$(\mathrm{mg} / \mathrm{l})$} \\
\hline & Cow ${ }^{*}$ & Humant & & $\operatorname{Cow}^{\bullet}$ & Humant \\
\hline $\begin{array}{l}\text { Retinol } \\
\text { Carotene }\end{array}$ & $\begin{array}{l}0.31 \\
0.18\end{array}$ & 0.60 & $\begin{array}{l}\text { Vitamin } B_{6} \\
\text { Vitamin } B_{12}\end{array}$ & $\begin{array}{l}0.40 \\
0.003\end{array}$ & $\begin{array}{l}0.06 \\
<0.0001\end{array}$ \\
\hline Vitamin D & & & Folic acid & 0.05 & 0.05 \\
\hline $\begin{array}{l}\text { cholecalciferol } \\
\text { vitamin D sulphate }\end{array}$ & 0.0002 & 0.0003 & Pantothenic acid & $0.3^{6}$ & 0.26 \\
\hline vitamin D sulphate & 0.0015 & 0.010 & Biotin & 0.02 & 0.0076 \\
\hline $\begin{array}{l}\alpha \text {-tocopherol } \\
\text { Vitamin K }\end{array}$ & $\begin{array}{l}0.9 \\
0.6\end{array}$ & $\begin{array}{l}3 \cdot 5 \\
0 \cdot 15\end{array}$ & Vitamin C & 20 & $3^{8}$ \\
\hline Thiamin & 0.40 & 0.16 & & & \\
\hline Riboflavin & $1 \cdot 90$ & 0.30 & & & \\
\hline Nicotinic acid & 0.8 & $2 \cdot 3$ & & & \\
\hline
\end{tabular}


stage of lactation, but the concentrations of the other fat-soluble vitamins are influenced by dietary intake and to a lesser extent by breed: for example, Channel Island cattle secrete milk containing more carotene than do other breeds. In contrast, the amounts of most vitamins in human milk are largely influenced by the amounts in the maternal diet (Kon \& Mawson, r950).

All the vitamins appear to be well absorbed from milk and milk products which make important contributions to our daily needs, particularly for vitamin A, riboflavin, thiamin, folic acid and vitamin $B_{12}$. The percentage contributions made by I pint of milk to the recommended intakes of a $5-7$ year-old child for some vitamins are listed in Table 3 .

Table 3. Contribution (\%) of I pint ( $0.57 l)$ of milk to recommended daily nutrient intakes (mg) of a 5-7 year-old child

$\begin{array}{lcc} & \text { Recommended intake } & \text { Contribution from milk (\%) } \\ \text { Thiamin } & 0.7 & 35 \\ \text { Riboflavin } & 0.9 & 100 \\ \text { Folic acid } & 0.1 & 35 \\ \text { Vitamin B } & 1.5 & 100 \\ \text { Vitamin A } & 0.3 & 60\end{array}$

Vitamin D is customarily classified as a fat-soluble vitamin and estimations of the concentration of the vitamin have usually been made on the lipid fraction extracted from a food. Recently it has become evident that this procedure leads to a substantial underestimation of the vitamin $D$ content of milk, particularly of human milk, since milks also contain vitamin D sulphate, a water-soluble conjugated form of the vitamin, which had previously been discarded during the analytical procedure (Sahaski, Suzuki, Higaki \& Asana, 1967; Le Boulch, GulatMarnay \& Raoul, 1974; Lakdawala \& Widdowson, 1977; Department of Health \& Social Security, 1977). If the biological activity of vitamin D sulphate in human milk proves to be similar to that of fat-soluble vitamin $D$, a breast-fed infant would receive about $0.9 \mu \mathrm{g}$ of vitamin $\mathrm{D}$ per $100 \mathrm{ml}$ milk, an intake sufficient to meet its needs; this would answer the longstanding query why breast-fed babies seldom show signs of vitamin $\mathrm{D}$ deficiency.

It is evident from Table 2 that except for nicotinic acid there is more of all the vitamins of the B complex in cows' milk than in human milk, so provided losses are avoided during the manufacture, heat treatment and storage of infant foods, cows' milk provides an excellent source of these nutrients.

Effects of processing. The fat-soluble vitamins are unaffected by thermal processing and studies of the losses of other vitamins during traditional procedures have established that pasteurization, UHT sterilization and the preparation of dried milks cause little loss but that in-bottle sterilization and the sterilization of evaporated milk may cause considerable destruction of thiamin, vitamin $\mathbf{B}_{6}$, vitamin $B_{12}$, folic acid and vitamin $C$. Concentration of milk by reverse osmosis causes little loss of vitamins but with ultrafiltration only the vitamins that are firmly protein-bound, such as vitamin $B_{12}$ and folic acid, are completely retained. 
Further losses of these vitamins and also of riboflavin and vitamin A may occur during storage of liquid products if they contain dissolved oxygen or are filled into containers that are permeable to oxygen or transparent to light.

The fat-soluble vitamins from milk are retained in the curd during cheese-making, but most of the water-soluble vitamins pass into the whey; there may, however, be microbial synthesis of some vitamins during ripening.

Water-soluble vitamins in milk and milk products were comprehensively reviewed by Gregory (1975).

\section{Minerals}

Values for the concentrations of the major inorganic nutrients and of some trace elements in cows' and human milk are given in Table 4 . It will be immediately evident from this Table that cows' milk contains a substantially greater concentration of electrolytes than does human milk.

Table 4. Concentrations of inorganic nutrients in cows' and human milk

\begin{tabular}{|c|c|c|c|c|c|}
\hline \multirow{7}{*}{$\begin{array}{l}\text { Calcium } \\
\text { Phosphorus } \\
\text { Sodium } \\
\text { Potassium } \\
\text { Magnesium } \\
\text { Chlorine }\end{array}$} & \multicolumn{2}{|c|}{$(g / 1)$} & & \multicolumn{2}{|c|}{$(\mathrm{mg} / \mathrm{l})$} \\
\hline & Cow & Human ${ }^{+}$ & & Cow ${ }^{*}$ & Humant \\
\hline & $1 \cdot 20$ & 0.35 & Iron & 0.5 & 0.7 \\
\hline & 0.95 & 0.15 & & & \\
\hline & 0.50 & 0.15 & Zinc & 0.35 & 0.3 \\
\hline & $\begin{array}{l}1.50 \\
0.12\end{array}$ & $\begin{array}{l}0.00 \\
0.03\end{array}$ & $\begin{array}{l}\text { Selenium } \\
\text { Fluorine }\end{array}$ & $\begin{array}{l}0.02 \\
0.10\end{array}$ & 0.08 \\
\hline & 0.95 & 0.43 & Iodine & 0.3 & 0.07 \\
\hline
\end{tabular}

Milk and most cheeses, though not cottage cheese, have for long been recognized as important dietary sources of calcium, but it is clear that many incompletely understood factors influence the absorption of calcium from milk as from other foods and that the retention of calcium in the body is not necessarily a function of calcium intake.

Relatively little is known in absolute terms about the efficiency with which minerals are absorbed from milk though it is generally considered that sodium, potassium and chlorine, and probably the other monovalent anions, are completely absorbed. The higher renal solute load that results from feeding on cows' milk rather than human milk may lead to overhydration and hypertonicity since the kidneys of young infants cannot efficiently excrete sodium. The increase in renal solute load caused by cows' milk may be of relatively little significance in most circumstances because the kidney merely excretes a more concentrated urine. It does lead to a smaller margin of safety against dehydration and for this reason milk foods for young infants are now being formulated with contents of sodium much closer to those in human milk.

Nutritional requirements for trace elements are not yet well defined but an 
increasing number of these elements are being recognized as important in infant nutrition (Hambidge, r 976). Apart from differences in content between cows' and human milk there may be differences in the efficiency with which the elements are absorbed from these milks. There is evidence, for instance, that iron is more efficiently absorbed from human than from cows' milk (McMillan, Landaw \& Oski, 1976). It seems likely that many of the trace elements are present in milk as protein complexes which may be species-specific and so influence the efficiency of absorption, as was recently shown for zinc (Evans \& Johnson, 1977; Eckhart, Sloan, Duncan \& Hurley, 1977). Further work is required both to establish the requirements for inorganic nutrients and to determine the factors that affect their absorption and metabolism.

\section{REFERENCES}

Burvall, A., Asp, J.-G., Dahlqvist, A. \& Oste, R. (1977). F. Dairy Res. 44, 549.

Cook, G. C. (1973). Swedish Nutrition Foundation Symposium XI. [B. Borgström, A. Dahlqvist \& L. Hambraeus, editors], p. 52. Uppsala, Sweden.

Dahlqvist, A. (1977). Post-grad. med. F., Suppl. $2,57$.

Dahlquist, A., Asp, N.-G., Burvall, A. \& Rausing, H. (1977). F. Dairy Res. 44, 541.

Dairy Facts and Figures (1977). Federation of UK Milk Marketing Boards, Thames Ditton, Surrey.

Department of Health and Social Security (1977). The composition of mature human milk. Report on Health and Social Subjects, No. 12 . London: HMSO.

Eckhart, C. D., Sloan, M. V., Duncan, J. R. \& Hurley, L. S. (1977). Science, USA, 195, 789.

Evans, C. W. \& Johnson, P. E. (1977). Amer. F. clin. Nutr. 30, 6 I I.

Fomon, S. J. (1974). Infant Nutrition, 2nd ed., Philadelphia : W. B. Saunders Company.

Gregory, M. E. (1975). F. Dairy Res. 42, 197.

Hambidge, K. M. (1976). Curr. med. Res. 4, Suppl. I, 44.

Hendrickse, R. G., Woodridge, M. A. W. \& Russell, A. (1977). Brit. med. F. i, 1194.

Kon, S. K. \& Mawson, E. H. (1950). Human milk. Special Report Series of the Medical Research Council, No. 269. London: HMSO.

Lakdawala, D. R. \& Widdowson, E. M. (1977). Lancet i, 167.

Le Boulch, N., Gulat-Mamay, C. \& Raoul, Y. (1974). Int. F. Vitamin and Nutr. Res. 44, I67.

McAllan, A. B., Merry, R. J. \& Smith, R. H. (1975). Proc. Nutr. Soc. 34, 90A.

McMillan, J. A., Landaw, S. A. \& Oski, F. A. (1976). Pediatrics 58, 686.

Paul, A. \& Southgate, D. A. T. (1978). The composition of foods. London: HMSO.

Rogers, G. F., Welch, J. G., Nilson, K. M. \& Smith, A. M. (1977). F. Dairy Sci. 60, 1559.

Sahashi, Y., Suzuki, T., Higaki, M. \& Asano, T. (1967). F. Vitam. 13, 33 .

Thomasow, J. \& Klostermeyer, H. (1977). Dt. Milchwoirt. 38, 1316. 